\title{
UMBRAL O LA AMBIGÜEDAD AUTOBIOGRÁFICA
}

\author{
Manuel Alberca \\ Universidad de Málaga
}

alberca en uma es

\section{Resumen}

En este artículo se exponen los rasgos más singulares de la autoficción española, las contradictorias razones de su desarrollo, la relación con la autobiografía y el lugar que ocupa entre esta y la novela. Para analizar y ejemplificar este conjunto de problemas, en la segunda parte del trabajo me refiero a la obra de Francisco Umbral, cuyas autoficciones juegan al escondite en el extenso jardín de la novela.

Palabras clave: autobiografía, autoficción, novela, Francisco Umbral.

\section{Abstract}

Umbral or the autobiographical ambiguity

In this article the most peculiar features of the Spanish autofiction are shown, as well as the contradictory reasons to explain its development, the relation with autobiography and the place where it stands between autobiography and the novel. To analize and exemplify this set of problems, in the second part of the article I refer to Francisco Umbral's work, whose autofictions play hide and seek in the endless world of the novel. Key words: autobiography, autofiction, novel, Francisco Umbral.

Alberca, Manuel. 2012.

Umbral o la ambigüedad autobiográfica.

Círculo de Lingüística Aplicada a la Comunicación 50, 3-24.

http://www.ucm.es/info/circulo/no50/alberca.pdf

DOI: http://dx.doi.org/10.5209/rev_CLAC.2012.v50.40619

(C) 2012 Manuel Alberca Serrano

Círculo de Lingüística Aplicada a la Comunicación (clac)

Universidad Complutense de Madrid. ISSN 1576-4737. http://www.ucm.es/info/circulo 
Índice

I 4

Tradición de ambigüedades 6

Autobiografía vs. fingimiento 7

Pacto ambiguo y efecto fantástico 11

II 14

Umbral en su escondite 14

Autoficción: proliferación y elipsis 16

El secreto 18

La página pendiente 20

III 22

Bibliografía citada 23

Obras citadas de Francisco Umbral 24

En 1977 Serge Doubrovsky bautizó como autofiction su libro autobiográfico Fils, al que subtituló de “novela” en la portada y lo definió en la contraportada como “ficción de acontecimientos y hechos estrictamente reales”1 . La autoficción sería, pues, una novela, en la que el autor, bajo su mismo nombre propio, se introduce como narrador y/o protagonista. No obstante, autoficción no significa para su 'inventor' libertad de inventar la vida, sino de buscar la verdad de la vida y de la identidad a través de un relato con los recursos propios de la novela del siglo XX. A este tipo de autoficciones las denomino "biográficas” para distinguirlas de las “imaginarias”, que se permiten licencias inventivas (Alberca, 2007, 181 y ss.). En la narrativa actual encontramos numerosos relatos, que responden con exactitud a los principios de la autoficción. También en España. A lo largo del siglo pasado y del comienzo del actual, desde Azorín

1 Este artículo forma parte del Proyecto FFI2010-16704 del Ministerio de Ciencia e Innovación "Autobiografías de estudiantes: una escritura inmediata" dirigido por la Dra. A. Caballé. 
y Unamuno hasta Goytisolo, Umbral, Cercas o Marías, la nómina de relatos que se adecuan al principio formal de autoficción propuesto por Doubrovsky (novela + principio de identidad nominal) constituye un conjunto extenso y heterogéneo, tal como se puede observar en un inventario necesariamente incompleto de los publicados en el siglo XX y comienzos del siglo XXI (Alberca, 2007, 301-307). Incluso, con anterioridad a 1900, lógicamente bajo una concepción de sujeto distinta a la actual, podemos encontrar ejemplos que cumplen las premisas autoficticias.

Doubrovsky pudo intuir el acierto de su 'invento' conceptual y neológico por la necesidad de acotar el espacio literario existente entre la ficción y la autobiografía. Lo que el francés no podía imaginar desde luego es que su hallazgo pudiese llegar a convertirse en un subterfugio para los escritores españoles que coquetean con la autobiografía, pero que, en el fondo, no tienen interés literario en arrostrar la veracidad que exige el pacto autobiográfico (Lejeune, 1975). Como es sabido, uno de los motores de la ficción ha sido y es, hoy tal vez más que nunca, la propia vida. Los escritores españoles obedecen también a esta pulsión autobiográfica. Sin embargo, a pesar de esta tendencia, la mayoría de nuestros autobiógrafos lo es a regañadientes, convencidos sólo por las posibilidades mercantiles de su desganado y tardío ejercicio, pues son minoría los que creen en la necesidad moral de la autobiografía y su categoría literaria.

Por su ambigüedad formal y pragmática, la autoficción parecería un 'producto’ cultural francés pensado para el 'mercado' español, pues encaja a la perfección con la tradición española, que hizo de la contradicción su modus operandi, consistente en suscribir una idea y ejecutar su contraria. Si la autoficción ha prendido en la literatura española con tanto vigor, frente al menor arraigo de otras aportaciones culturales francesas, como las que se derivaron, por ejemplo, de la ilustración, es porque el mecanismo autoficticio se adapta bien a determinadas características españolas. Aunque en la forma y en las estrategias narrativas la autoficción española no difiera de la francesa, estoy convencido de que, en razón del diferente contexto histórico y literario, no significan lo mismo en los dos países y desde luego cumplen una función distinta. 
Tradición de ambigüedades

En la historia española se encuentran razones y motivos que permiten afirmar que los españoles estábamos muy 'preparados' (perdón por la ironía) para que el invento francés tuviera entre nosotros tan buena acogida, puesto que en nuestra historia existe una continuidad de ambigüedades e indeterminaciones. Como estado europeo España tiene una historia atípica y excepcional. Para empezar España es, sin dejar de ser europea, la nación que, por su emplazamiento geográfico (al sur de Europa y vecina a África) y por los azares de la historia misma, ha vivido durante siglos bajo la influencia de dos religiones (cristianismo e islamismo) y de dos culturas (occidental y oriental), que dividió el territorio en dos partes opuestas, con las complicidades, tensiones y enfrentamientos que esto conllevó. Con respecto a Europa nuestra cultura fue durante siglos excéntrica en lo cultural, en lo político y en lo religioso. Los esfuerzos para volver al centro europeo han sido paulatinos y vacilantes, muchas veces traumáticos, como ocurrió a lo largo del siglo XIX en que los enfrentamientos entre liberales y tradicionalistas dieron lugar a tres guerras civiles, cuyos efectos llegan hasta hoy.

En 1839 terminó la primera guerra carlista, en realidad una disputa dinástica sólo en apariencia, pues en el fondo fue un conflicto civil en que se enfrentaron dos posturas en apariencia irreconciliables: liberales y tradicionalistas. Con la derrota militar de los carlistas, se ponía fin a unas hostilidades que ensangrentaron el país durante casi seis años. Dicha derrota no impidió que la guerra civil se repitiese dos veces más a lo largo del siglo con igual resultado. La ley de 25 de octubre de 1839, resultado del acuerdo que puso fin a la guerra, con la rendición carlista el 31 de agosto del mismo año, conocido como el "abrazo de Vergara”, lejos de ratificar esa victoria, consagró una fórmula mixta por la cual se mantuvieron los fueros y los privilegios (leyes antiguas de origen medieval) de las provincias del norte (Navarra y las provincias vascas), con el curioso y contradictorio estrambote que apostillaba: "sin perjuicio de la unidad constitucional de la Monarquía” (Fontana, 173).

Esta solución, que se entiende por historiadores y juristas como un monumento a la ambigüedad, marcó el desarrollo de los siglos XIX y XX, y lamentablemente parece que marca todavía el comienzo del siglo XXI, pues ciento cincuenta años después, en 1978, 
en la constitución hoy vigente en España, se puede leer una fórmula tan ambigua como la decimonónica: “amparar y respetar los derechos históricos de los territorios forales, sometiendo su actualización al marco constitucional”. El régimen democrático, establecido por la constitución de 1978, arrumbó y abolió todos o casi todos los vestigios de la dictadura que la precedió, pero nadie ignora que el restablecimiento de la monarquía y, en consecuencia, el régimen democrático actual, se reinstaura a partir de leyes propuestas por Franco y refrendadas por las Cortes de la dictadura. Las dos fórmulas legales, la de 1839 y la de 1978, representan un desideratum por el cual se intenta armonizar los principios del antiguo régimen con los del estado liberal-burgués. A esto hay que añadir los escolios tradicionalistas que subsisten en las reivindicaciones de los nacionalismos periféricos (catalán y vasco sobre todo), y la postura ambigua con respecto a estos de los partidos políticos de izquierda y derecha, sobre todo, de los primeros en clara contradicción con sus principios internacionalistas e igualitarios. Por otra parte, la persistencia de algunos sectores de la jerarquía eclesiástica, que quiere seguir ejerciendo una misión tutelar, no se compadece con las sociedades libres que ella misma reivindica.

No me extenderé más en este capítulo histórico, pues si me refiero a esto es sólo para resaltar que en España no nos parecen imposibles normativas y leyes ambiguas, nacidas del deseo de hacer viables posiciones contrarias e irreconciliables, con la intención de que los hechos desagradables o las realidades molestas se escondan debajo de la alfombra con fórmulas legales o que, lejos de resolver los conflictos, acostumbremos a disfrazarlos.

Autobiografía vs. fingimiento

« J'aime l'autobiographie. J’aime la fiction. J’aime moins leur mélange. Je ne crois pas qu'on puisse vraiment lire assis entre deux chaises » (Lejeune 2007, 3). Una afirmación como esta, que distingue con claridad la ficción de la realidad, expresa una inequívoca normalidad autobiográfica en Francia, tanto más deseable desde España, en donde nos hemos educado en una tradición en la que es posible defender en teoría una posición y 
actuar basándose en su contraria. España es un estado moderno, pero en el que subsisten demasiados rasgos premodernos. En consecuencia sufrimos graves problemas identitarios de todo tipo con lo que esto tiene de rémora. Por ejemplo, es frecuente encontrar personas agnósticas o indiferentes, incluso ateos confesos, que defienden la celebración de los desfiles procesionales de Semana Santa con toda su parafernalia inquisitorial apenas revisada.

El hombre es tal vez el único animal capaz de fingir por puro placer teatral o por gusto de disfrazarse, pero también por necesidad o por conveniencia social, hipócrita o no. En fin, se trata de la capacidad de simular papeles que en su fuero interno no reconoce como propios ni sinceros. No pretendo mantener, por tanto, que la simulación o el fingimiento con la que yo relaciono la autoficción sea un rasgo exclusivo de los españoles, pues dicha pulsión debe estar inscrita en el mapa genético humano, pero creo que en España la escuela de fingimiento ha alcanzado una perfección encomiable.

Entre nosotros, el fingimiento es, antes que una opción lúdica, una necesidad social, un aprendizaje necesario ante intransigencia que anida en nuestros espíritus. Fingir lo contrario de lo que se piensa, aparentar ser el que sabemos que no somos, simular lo contrario de lo que nos gustaría hacer, disimular nuestro déficit, es una urgencia, un principio de salvación, de autodefensa o de camuflaje. Ante una sociedad hostil, el individuo se protege asumiendo los papeles sociales de forma teatral: ser otro para los demás sin dejar de ser uno para sí mismo.

Por todas estas razones, en España se percibe una (re)presión anti-autobiográfica quizá mayor que en cualquier país de nuestro entorno cultural, represión que tiene mucho de residuo inquisitorial, pues se caracteriza por interesarse por la vida privada de los otros de forma controladora, con el fin de menoscabar el ánimo de los que desafían el reto de contar su vida y ponerla por escrito. Esta resistencia ante la autobiografía tiene su origen en la larga tradición ya referida. Tampoco es ajena a este retraimiento confesional la influencia que supuso un periodo de 40 años de falta de libertad, de censura y autocensura que conllevó la dictadura franquista. Desde hace más de tres décadas la 
autobiografía española trata de salir con esfuerzo de esa herencia doble: la represión anti-autobiográfica y el correspondiente disimulo.

En mi opinión, este panorama, apenas aquí esbozado, pone en evidencia las limitaciones de nuestra autobiografía y explica que ésta se haya decantado hacia formas de autobiografismo prudente y escondido, que resulta a todas luces más pre-moderno que posmoderno. La adopción de una apariencia de posmodernidad resulta más una estrategia de simulación o disimulo pro domo que un descreimiento, una excusa para no tener que afrontar los retos históricos y sociales que la autobiografía española no se atreve siempre a afrontar. A diferencia de lo expuesto por Lejeune, los españoles nos hemos educado en esa suerte de malabarismo que consiste en interpretar los textos de modo vacilante, deviniendo en maestros en el difícil arte de “leer entrelíneas”.

La autobiografía, tildada peyorativamente de narcisista, sufre entre nosotros un ancestral menosprecio. Resulta realmente ingrato, cuando no hostil, para las personas que, de manera libre y sin pedir nada a cambio, salvo una escucha atenta, hacen el regalo de contarnos su vida. Este acto de exponerse en público, sin máscaras ficticias ni líricas difuminaciones, ha sido y sigue siendo entre nosotros un acto doblemente arriesgado, pues a su dificultad literaria intrínseca se une además el rechazo moral, que cabe relacionar con reflejos inquisitoriales o dictatoriales en el comienzo del siglo XXI. No en vano durante siglos la práctica confesional fue patrimonio exclusivo de la iglesia católica, que vio en el ejercicio de hablar de sí mismo o de escribir la propia vida, sin estar dirigida a Dios, al confesor o autoridad eclesiástica, la manifestación del pecado de soberbia. Igualmente exaltar el valor de lo individual o defender lo personal frente a la norma social convertía inmediatamente a quien lo defendía en alguien sospechoso. Por esta razón, y especialmente en nuestro país tan reacio históricamente a la manifestación libre del yo, la autobiografía, incluso la novela autobiográfica, han sido calificadas de exhibicionistas, y consideradas un acto de vanidad, en fin, una ostentación orgullosa del propio yo. En este panorama el yo autobiográfico resulta culpable de fatuidad, soberbia o narcisismo. En la tradición autobiográfica española, tan abocada al pecado de autocomplacencia como al disimulo hipócrita, cuando menos se recela de él o se le menosprecia. La situación de la autobiografía española en el pasado se comprende 
mejor si se compara con las de nuestros vecinos del sur (Marruecos y Argelia) en donde la influencia religiosa y cultural ha impedido la emergencia del yo escrito sin ataduras ni disfraces. La literatura del Magreb no ha desarrollado la escritura autobiográfica o la ha vehiculado sólo bajo el manto protector de la ficción (v. Hernando de Larramendi y otros).

Los escritores y críticos literarios españoles no aprecian por lo general el servicio inestimable que los autobiógrafos rinden a la higiene mental del país, al asumir el desafío de escribirse y de compartir aquello que les singulariza y les constituye íntimamente. Al contrario, entienden la práctica autobiográfica como un síntoma de debilidad íntima o de soberbia ególatra. Además del juicio peyorativo que en España padecen autobiografía y autobiógrafos, cabe señalar también una discriminación literaria (que no es específicamente española), consistente en considerar la autobiografía una literatura de menor rango estético que la ficticia. Los escritores (incluso entre los que han publicado su autobiografía) y los críticos periodísticos y académicos coinciden en considerar la literatura autobiográfica una escritura de segunda división, muy por debajo de las obras de ficción, que para ellos es la literatura con mayúsculas.

La rémora que sufre la autobiografía en España nos da alguna de las claves del desarrollo de la autoficción española en las últimas décadas. El número creciente de autoficciones, que no se podría entender fuera del paralelo y simultáneo crecimiento editorial de la autobiografía en los 30 años últimos, es un ejemplo del ambiente confesional, pero también de sus limitaciones. El actual auge de las autoficciones se beneficia del reclamo que lo autobiográfico despierta en los lectores, pero, al mismo tiempo, el hecho de presentar como novelas relatos de contenido o forma autobiográficos permite evitar los dos escollos en los que la autobiografía española suele encallar: la discriminación literaria y los compromisos morales y riesgos sociales que se derivan de enfrentarse a la verdad. 
Pacto ambiguo y efecto fantástico

Frente a la autobiografía y su pacto de lectura, la autoficción propone una particular pragmática lectora, que se caracteriza por moverse entre el pacto novelesco y el autobiográfico. La autoficción es una cuña entre ambos. Incorpora elementos de los dos en proporción y forma variable, para inclinarse bien hacia la ficción o bien hacia la autobiografía. Por la mezcla de elementos antitéticos, propios de géneros distintos, la autoficción podría ser considerada un híbrido literario. Se encuentra en medio de un movimiento de doble dirección: la deriva de la autobiografía hacia la ficción, al adoptar el lenguaje y los recursos propios de la novela, y la invasión colonialista, del territorio autobiográfico, por la novela.

Las autoficciones establecen con sus lectores un 'pacto ambiguo' de lectura, que es también una declaración de no-responsabilidad, prevención o temor, que les lleva a ocultarse tras el disfraz o jugar al escondite, antes que a aceptar el compromiso y riesgo que conlleva el pacto de veracidad (Alberca, 2007, 125-157). Este pacto se caracteriza por incluir en una misma propuesta dos términos o premisas antitéticas, que quedan armonizados bajo una forma paradójica que disimula la contradicción, pero sin hacerla desaparecer. Escudado en una serie de protocolos de lectura que en puridad son ambiguos, el autor puede afirmar y negar su identidad al mismo tiempo: "Yo no soy yo evidentemente”; “yo soy y no soy yo”; “mi vida no tiene interés y además no me acuerdo”, como dice el narrador de Ramón Buenaventura en El año que viene en Tánger. Del mismo modo puede añadir prólogos, notas aclaratorias o instrucciones de uso que añaden argumentos a la confusión: “Esta novela que no otra cosa es por más que a alguno le pueda parecer una autobiografía (toda novela es autobiográfica y toda autobiografía es ficción), se sitúa en una época y en unos escenarios que existieron realmente” (Julio Llamazares, La lluvia amarilla).

La mezcla de elementos contradictorios y de propuestas indeterminadas da como resultado textos narrativos de apariencia autobiográfica, que bien podrían ser verdaderas autobiografías, más o menos camufladas (es decir, falsas novelas), o bien falsas autobiografías (es decir, verdaderas novelas que simulan ser relatos autobiográficos). A pesar de su variedad, esta franja entre ambos campos se caracteriza sobre todo por un 
tipo de ambigüedad que deja al lector vacilante: ¿novela o autobiografía? Ambas soluciones son posibles según se entienda como invención o como verdad, aunque también no es menos cierto que entre los dos extremos caben infinidad de grados. Cuanto más sutil sea la mezcla de elementos contradictorios, más se prolonga la sensación de insolubilidad para el lector y mayor será su esfuerzo para resolver la duda. El problema reside en el desconocimiento del grado de veracidad y en el desvío que, sobre los hechos, el autor ha operado.

Como ya adelanté al comienzo, la autoficción permite acotar una zona fronteriza entre los relatos factuales y los ficticios. Desde su posición limítrofe quedan subvertidos tanto los principios novelescos como los autobiográficos. Algunas ideas de ambas clases de relatos, como son la veracidad autobiográfica y la libertad imaginativa de las novelas, son trasgredidas al cuestionar tanto la referencialidad externa de las autobiografías como la autonomía referencial de las novelas. La interpretación que se ha dado a la autoficción ha oscilado entre la versión 'realista' de Doubrovsky, que la considera un testimonio personal, y la 'imaginaria' de Colonna (2004). Para el primero la autoficción sería en realidad una variante de la autobiografía con una mayor libertad en el discurso narrativo que la autobiografía convencional. Para Colonna, la autoficción podría considerarse un tipo de novela que ha transgredido la última instancia realista que le quedaba por subvertir: el nombre propio del autor. Al concederle a éste un uso novelesco, pierde casi su valor referencial, subvierte el código autobiográfico, pero también anula el principio de distanciamiento característico de las novelas, según el cual el autor desaparece o se borra del texto, camuflándose tras la figura de un narrador o protagonista heterónomo (Darrieusecq, 1996: 371-373). En razón de esto, la autoficción exige una lectura particular, un ir y venir entre ambos polos, que insta al lector a moverse entre ambos. Por su apariencia autobiográfica, tendemos a considerar los hechos y datos de las autoficciones como pertenecientes al autor y su vida real. Hasta que, en el paratexto y/o en el texto, irrumpen de manera imprevista signos que nos hacen dudar de su veracidad. Esta duda puede disolverse o por el contrario perdurar. 
Algunas autoficciones utilizan un mecanismo similar al utilizado en los relatos fantásticos y, en consecuencia, tratan de producir su misma indeterminación o característico “efecto fantástico” (Todorov, 1970). Tal como éste lo define, la 'historia' de los relatos fantásticos está construida sobre un juego de elementos que hacen bascular el relato entre lo natural y lo sobrenatural hasta el final del texto. Esa vacilación es la que impide que el narrador o protagonista, y el lector con él, puedan darle una interpretación definitiva a la 'historia', manteniéndose indeciso su desenlace real o irreal. El lector desea y quiere encontrar una solución que le saque de la duda, pero el texto no se la da ni se lo permite. La ambigüedad se prolonga y permanece más allá del final (Todorov, 1970: 34-44 y 186-199). La indeterminación infinita es también el objetivo o meta de algunas autoficciones, que querrían conseguir la indefinición de lo fantástico. Pero, hay que advertirlo: esa clase de vacilación lectora pocas veces se encuentra en las autoficciones. En la mayoría de estas, dicha indeterminación es muy superficial: una mera cuestión de ambigüedad en el paratexto, que se resuelve a poco de comenzar el relato. En otras, el artificio novelesco o metaficticio es tan evidente que revela su carácter puramente novelesco. Hay una tercera posibilidad en la que el autor aspira a crear la máxima ambigüedad, proyectando ésta a todo el texto. Si bien el autor aspira a hacer insoluble el enigma autobiográfico del relato, el lector desea resolver dicha vacilación hacia uno de los dos dominios narrativos. Pero son pocas las autoficciones que producen esa indeterminación interpretativa: o el final del texto diluye la ambigüedad o el lector desvanece la duda interpretando el relato como autobiográfico o como ficticio. En conclusión, el mantenimiento de la duda durante la lectura puede perdurar, pero finalmente, más pronto que tarde, la tendencia del lector es dar fin a la incertidumbre. El lector comprende que se trata de un texto autobiográfico con más o menos velos o escondites, o se abandona a la verosimilitud novelesca sin cuestionarse su posible veracidad. Sin embargo, a pesar de esta decantación hacia uno de los dos pactos, lo particular de las autoficciones es su resistencia a ser leídas de acuerdo a un solo estatuto, su pretensión, pocas veces lograda, de prolongar ad infinitum las incógnitas y misterios del texto. 
II

Voy a ejemplificar la ambigüedad autobiográfica y uno de los usos de la autoficción en España a través de la obra de Francisco Umbral. Como ha quedado dicho al comienzo de este texto, Umbral no fue ni el primero ni el único escritor español que se acogió a la libertad que permite la autoficción, pero ninguna obra de este periodo del tardofranquismo y de la transición española (décadas de los 70 y 80) muestra una relación angustiosa entre la auténtica vida y la necesidad de simular otra.

Umbral en su escondite

La biografía y personalidad de Umbral son hijas del ambiente en el que creció durante la dictadura franquista, pero también son deudoras de la transición a la democracia y de sus limitaciones. Su obra, que tantas veces se ha relacionado con la transición española a la democracia y considerada un símbolo de la entonces recién conquistada libertad, es un exponente de no saber qué hacer con esa libertad a la hora de rememorar el pasado personal. Umbral como autobiógrafo es un buen ejemplo del forcejeo entre la búsqueda a cara descubierta de la verdad de uno mismo y el retroceso patético y medroso ante ésta. Sus razones son similares a la de tantos autores que consideran la autobiografía un ejercicio literario menor, simple testimonio sin valor artístico, un recurso para escritores sin recursos y al final de su carrera. Sin embargo, su propia vida se constituyó evidentemente en el venero más rico de su obra. En este desprecio explícito, reiterado tantas veces por Umbral, se detecta algo más que un lugar común, se detecta sobre todo su impotencia: el temor del que no puede o no sabe hacer frente a un reto necesario en el que le va la vida. El subterfugio de la ficción es algo más que una forma de estilizar la experiencia, representa la única manera también de seguir hablando de lo que le obsesiona, pero de una manera oblicua y balsámica. Su obra manifiesta cuánto debe a su vida, y en consecuencia a la autobiografía, a la que no obstante menosprecia por carecer, a su parecer, de categoría literaria. Por eso, el escritor madrileño hizo del estilo una mixtificación de esa libertad y lo convirtió en una fuerza autónoma: “la escritura es el río que nos lleva”, ha escrito en alguna ocasión. La perseguida conquista de un estilo es el logro alcanzado, a cambio del cual se renuncia al verdadero relato autobiográfico. La utilización de la primera persona y de la 
forma aparentemente autobiográfica deviene en un recurso retórico para esconder o disfrazar su yo velado, su infancia y sus orígenes.

Umbral fue un escritor obsesionado por la observación minuciosa y detenida de su propio yo. Da la impresión de no querer o no poder salir de su único tema: él mismo. Su obra aborda este mismo asunto de manera obsesiva, pues sus numerosos libros dan vueltas en torno a su personalidad y a sus diferentes trasfiguraciones. Es la suya una manera de enmarañar y ocultar su escondido y problemático (para él sin duda lo era) origen familiar. Y hay también en esta orientación de su obra un lado mercantil. Umbral fue ante todo un escritor profesional, es decir, hizo de la pluma su modus vivendi, lo que le obligó a prodigarse en exceso. En sus épocas de febril actividad escritora, además de sus múltiples colaboraciones en la prensa, e impelido por compromisos editoriales (y también por una tendencia compulsiva a estar omnipresente y a prodigar su nombre por todas partes), llegó a publicar en algunos años hasta 11 libros (Caballé, 2004). No obstante, en su proliferante creación, actúa con la prudencia del que temiera contar la verdad, agotando así posiblemente el venero más caudaloso de su escritura, su propia vida. Así baraja los episodios de su vida y cambia los argumentos y razones sin dar ninguna explicación. Se intuye que hay en ello mucho de compulsión: una necesidad íntima e inconfesable de borrarse y afirmarse, de regatear y esconder entre la proliferación barroca de la palabra y de las sucesivas versiones y distintos relatos, el núcleo tabú, secreto y vergonzoso al que es incapaz de abordar de frente y por lo derecho. Se trata en definitiva de utilizar la fronda del lenguaje como refugio o escondite para no tener que afrontar el nudo sin desatar de su vida y de su obra. En honor a la verdad Umbral tiene libros en forma de diarios en los que resulta conmovedor cómo expresa sus dudas, sus limitaciones y sus miedos con clarividente y brillante precisión, pero siempre sin decir las causas: "No se puede huir de la propia autobiografía, no se puede huir de la Historia. Esas huidas se pagan” (Diario de un escritor burgués, 1979). Y es que buena parte de las autoficciones de Umbral giran en torno a un centro elidido, revelado sólo a medias y a través de proliferantes y diferentes versiones. La ocultación del pasado infantil del autor y su calculado y confuso desvelamiento posterior, que presiden este tipo de relatos, responden tanto a una fuerza creativa y literaria como a una urgencia psicológica, es decir, una manera de calmar el dolor de una antigua herida sin cicatrizar. 
Autoficción: proliferación y elipsis

¿Cuáles son las figuras retóricas de esta biografía fabulada? Las autoficciones de Umbral a las que me refiero se basan en un doble movimiento creativo, uno de carácter proliferante y otro elíptico. Es decir, las novelas amplían profusamente una biografía que se cuenta y se recuenta en múltiples y diferentes versiones, y en consecuencia no concluyen nada, pues evitan el centro. Proliferación y elipsis podrían parecer dos movimientos contrarios, pero en la obra de Umbral resultan complementarios. Ambos corroboran la idea “creativa” que tuvo siempre de la escritura autobiográfica. En un pasaje del prólogo de Los males sagrados (1973), se puede leer: “Le oí decir a un realista español que lo autobiográfico sólo da cuarenta folios, pero hay que procurar que dé cuatro mil, u ocho mil, como le dio a Proust, porque es, así entendido, lo único novelesco que llevamos en nosotros” (“Infancia y novela”, Los males sagrados 11). A él no le dio para tanto, pero la novela de la infancia se prolongó sin tino. Desde aquella novela de 1973, la autoficción creció, dando vueltas a cada una de las ramificaciones posibles de su relato de infancia.

Umbral era consciente del ejercicio de revisión y reescritura que cada periodo de la vida hace del anterior: “... el hombre está repasando siempre el libro de la vida, en el que todos leemos, pues lo vivido se va tornando novela, el pasado se consagra sólo y nos va consagrando”, dice el narrador de Las ninfas. Como es sabido, a cada vuelta del camino de la vida el pasado cambia y se nos muestra con una diferente perspectiva y con otro tono. Nada que objetar por tanto. Lo que se puede y se debe advertir es que, a pesar del entramado intertextual que forman sus autoficciones, cada "repaso" no supone un esclarecimiento de la novela del “yo” umbraliano, sino proliferantes y superpuestas versiones de unos hechos que a cada aproximación pierden más sus contornos.

Con un ejemplo se entenderá mejor lo que digo. Las autoficciones de Umbral tienen casi siempre como centro, o al menos como figura omnipresente, a la madre, pues como Umbral deja escrito: “... la literatura no es otra cosa que el yo. El yo o la madre. La madre. Es lo mismo” (Los Cuadernos de Luis Vives, 14). Por tanto, todo gira en torno o bascula hacia la madre, que en la mayoría de las veces es una ausencia omnipresente, una entidad que se resiste a ser apresada. En Las ninfas, la madre es una ausencia 
magnética, pues allí se cuenta la difícil separación de ella y la búsqueda de su ideal en otras mujeres. En Las ánimas del purgatorio, la madre está suplantada por la figura de la tía Algadefina y en Los males sagrados y El hijo de Greta Garbo, la madre es la metáfora de la enfermedad y de la convalecencia física y política, la metonimia de un vestido blanco con una mancha roja, la cama acogedora o vacía, el reflejo en un espejo o la evocación del rostro de una star. La madre es finalmente el espacio hueco de la muerte, la presencia-ausencia más allá del tiempo, en la memoria, y el ingreso definitivo en la madurez. La madre es el imán innegable de estos relatos, y aunque de ella disponemos múltiples imágenes, en realidad, desconocemos casi todo. En el centro de la novela de la infancia hay, por tanto, un vacío elocuente, algo que se resiste a ser expresado, por desconocido, inalcanzable o temido. En cada novela pugna con ese centro tachado y enigmático, y a su manera, lejos de elucidarlo, lo dobla. Si el hipertexto novelesco se organiza en torno a un centro ausente, propaga por fuerza otro $u$ otros centros, cuya figura espacial es la elipse: el círculo deforme y sin centro.

Umbral es consciente de esta carencia, y cuando se propone escribir Los cuadernos de Luis Vives parece que está decidido a poner el centro que falta y a cerrar el círculo:

La novela de mamá la he contado muchas veces, como novela y memorias. Hay en esto tanta devoción materna como imagen literaria. Lo sobrecogedor de la literatura es que hasta la propia madre, cuando la escribimos, se vuelve literatura (...). Este es el personaje literario del que he usado y abusado en mis libros (...)

He dado tantas veces la madre literaria que quisiera dar ahora, en este libro de las verdades (...), la madre real, cotidiana, mortal, aunque al final resulte que era más real la otra, la inventada: uno cree ya más en la literatura que en la vida.

Al final de ese libro, después de 180 páginas de intentar apresar la "madre real”, el autor reconocerá que es incapaz, que nuevamente el centro se le resiste, quizá porque esté hueco o porque resulte inalcanzable ya para él, que hace tiempo decidió habitar en la elipse literaria, en el centro metafórico: “¿Estoy haciendo literatura? Entonces es mejor 
dejarlo”, concluye. Umbral tiene la intención de cerrar aquí el largo discurso sobre la madre, es decir sobre el yo, sin haber conseguido esclarecerlo ni dado una respuesta satisfactoria a tanta incógnita.

Similar proliferación o escamoteo se realiza con la muerte de la madre, con la iniciación sexual del adolescente, con la salida de la provincia, etc. Ahora no tengo espacio para detenerme en las diferencias y matices de las distintas variantes que de estos hechos se encuentran en las novelas, pero quede anotado tan relevante aspecto. De tantas versiones como tenemos no se podría conjeturar ninguna como verdadera, aunque quizá su significado no es otro que la firme decisión de abandonar el centro biográfico real y desplazarse a otro, donde la escritura suplanta a la vida.

\section{El secreto}

¿Qué había en el centro elidido? ¿Qué hecho biográfico bordea Umbral sin tocarlo o emborrona al contarlo? ¿Cuáles son esas reminiscencias de la "misteriosa memoria infantil”, como él la denomina? ¿Qué palabra quedó sin ser dicha en medio de los millones de palabras escritas? ¿Qué querrá decir “la tristeza simple, la soledad sencilla e inconsolable que me habita, aquella cocina apagada que llevo en el pecho: eso sigue ahí, callado, nunca dicho”, que Umbral anota en su Diario de un escritor burgués? ¿Cuál era en definitiva su secreto?

Interrogantes e incógnitas que la biografía de Anna Caballé (2004) se propuso responder. En su exhaustivo trabajo, la biógrafa documentó lo que eran rumores o sospechas a raudales, muchas de ellas provocadas por el mismo autor que, como he dicho, una vez contaba la versión A, después la B, a continuación la C..., esparciendo tal cantidad de contradicciones y dobles versiones que el lector más crédulo de la verosimilitud novelesca no podía por menos que establecer relaciones extratextuales. El reiterado y elusivo relato de la madre, las diferentes versiones de su muerte, la fantasmagórica presencia de un padre siempre ausente, la impostura de una genealogía familiar nobiliaria, etc., tejen una selva en la que el lector acaba por rendirse, vencido por el encantamiento de un estilo que desrealiza o sublima lo vivido. Esta red narrativa 
señala el nudo gordiano de un escritor que no se atreve o no puede desenredarlo. En este caso, como en cualquier novela familiar, el mito personal parece emanar, más o menos conscientemente, de un trauma y de la dificultad de asumirlo.

La revelación de la verdadera biografía infantil, tantas veces ficcionalizada por Francisco Umbral y revelada finalmente por Anna Caballé (2004), permite leer la obra con una base auto/biográfica que antes sólo podíamos sospechar. Al disponer de la información biográfica, comprendemos lo que las novelas tenían de elaboración mítica y de autoficción. La obra de Umbral muestra cómo la construcción de un personaje literario puede ser una operación sumamente ventajosa para el escritor y sus intereses, una operación que le permite difuminar los aspectos personales que el considera más negativos, inventando otros positivos, o rescatar del pasado sólo aquellos aspectos que el autor considera más convenientes a sus intereses.

Umbral fingió una y otra vez su biografía, sembrando un complejo repertorio de novelas sobre su infancia. Por su parte, Caballé esclareció, además de su verdadera fecha de nacimiento, el resto de las circunstancias de su nacimiento y demás circunstancias de sus años infantiles. En apretado resumen los hechos más decisivos, a mi juicio, serían los siguientes:

...Francisco Umbral es un nombre literario. El nombre que figura en su carné es el de Francisco Pérez Martínez y nació en La Inclusa de Madrid el 11 de mayo de 1932 (y no de 1935, como asegura la leyenda). Su madre, Ana María Pérez Martínez, había nacido en un pueblo de la provincia de León, en Valencia de Don Juan, a primera hora de la mañana, el día 7 de octubre de 1905. Era hija mediana de una familia de labradores [...]. Lo ignoramos todo del padre de Umbral. Fuera quien fuese se desentendió de la situación creada, acaso ni siquiera llegó a ser consciente de ella (Caballé, 1999, 10-11). 
El resto de la infancia vivió con la familia de su tío materno, sin saber hasta la adolescencia que los que él llamaba “padres” resultaron ser sus tíos y que la que él creía su tía resultó ser su madre. De su padre supo a través de su madre muy tardíamente.

A partir de estos datos, conocemos las verdaderas razones del calculado recurso a la ficcionalización biográfica, y el intento de camuflarse tras un pseudónimo. Este cambio de nombre podría parecer una mera cuestión de sonoridad, pero como ha mostrado la investigación de Anna Caballé el cambio no fue desinteresado o meramente artístico, pues borrando sus verdaderos apellidos buscaba prolongar la confusión y ocultamiento que efectúa en sus autoficciones, al tiempo que intentaba disimular la mancha de lo que él siempre consideró una deshonra. Detrás de un pseudónimo, por banal o transparente que parezca, suele esconderse siempre un problema o un misterio, una fantasía frustrada y un mito. En un pseudónimo artístico, como el que nos ocupa, se esconde o se alimenta normalmente la esperanza de un triunfo, que es tanto más deseado cuanta más necesidad se tiene de resarcirse de alguna carencia personal o social. En principio el apellido Umbral es una firma de autor, pero tras la que se ocultan sus verdaderos y comunes apellidos Pérez Martínez, ambos de su madre, pues su padre no le reconoció. Además de difuminar una genealogía familiar conflictiva, tras el Umbral, Francisco Pérez Martínez se creaba un halo artístico, imprescindible para él, que hizo del éxito un objetivo inaplazable, compensatorio de su maltrecha biografía infantil, para encontrar en la entrega a la escritura, de manera desaforada y compulsiva, su salvación.

La página pendiente

De acuerdo con estos hechos, las autoficciones de Umbral se convierten en un espacio privilegiado en el que el autor se invente su pasado. Camufla a veces y oculta en otras el secreto que le constituye de manera íntima, pero que le hace sentir frágil ante los demás. Nadie como Umbral, en novelas como Los males sagrados, Las ánimas del purgatorio, El hijo de Greta Garbo y en general toda la serie de "novelas de la madre y de la provincia” (como el propio autor las denominó), y desde luego nadie de manera tan insistente, ha creado un mito personal, que, partiendo de algunos elementos verdaderos 
de su biografía, haya construido una historia tan contradictoria, al tiempo que estilizaba o evitaba los aspectos menos gratificantes de sus orígenes.

Tanto el ocultamiento del autor como la expectativa del lector, atento a las estrategias de disimulo, disfraz y escondite del primero, no se comprenderían o resultarían banales, si no existiese el tabú o el secreto familiar, que Umbral cuenta de manera embarullada en los márgenes de la ficción y del disimulo. Como la mayoría de este tipo de novelas, las de Umbral se organizan y cobran sentido en torno a un secreto familiar, que él vivió de manera avergonzada, y cuyo ocultamiento late en los relatos. Ese secreto, el autor no supo o no pudo canalizarlo más que ocultándolo y después revelándolo en fragmentos calculados y contradictorios y siempre tras la máscara de la ficción. El secreto, sea del tipo que sea, si es un verdadero secreto, revela su fuerza contradictoria en la necesidad de compartirlo con otros y en el riesgo que conlleva revelarlo en la medida que le hace vulnerable. La revelación de lo nunca antes contado, aunque sea en el molde de una ficción, tiene para el autor la innegable ventaja de poder verbalizar el tabú y de liberarse de la carga de su prohibición, es decir, cumple una función catártica. Al mismo tiempo la protección de la ficción le defiende de la penalización que normalmente conlleva la trasgresión de los límites al infringir los códigos sociales, sin exponerse a sus riesgos. Las autoficciones de Umbral son un ejemplo de la gestión errónea del secreto y la tremenda carga de fracaso que conlleva no hacerle frente. La pulsión por contarlo, pero ocultándolo en realidad tras una profusión de versiones diferentes, no se entendería sin esa tensión entre la transmisión de lo íntimo y el cálculo ficticio para no quedar expuesto a los riesgos que implican revelarlos. La imposibilidad de abordarlo da idea de su pervivencia y de su peso, así como la dificultad de liberarse de él.

Sin esta referencia biográfica y sin el conocimiento de las claves vitales que las sustentan, las novelas de Umbral se tornan elípticas y hasta incomprensibles. Tejen una trama de motivos que pasan de una a otra, cambian en su presentación y se multiplican en versiones, hasta hacer prácticamente imposible la compresión de ese mundo oculto, evocado y, al final, mitificado. Quizá para algunos, incluido para el propio autor, haya en esta elección un sacrificio en aras de la belleza y la literatura pura. Para el que suscribe, Umbral dilapida un 
potencial literario impresionante: desaprovecha los hechos reales de su auténtica biografía, de mayor interés que la versión estilizada de sus autoficciones.

Umbral era plenamente consciente de las limitaciones de su obra y lo era sobre todo de no haber afrontado nunca un relato verdadero de su auténtica vida, pues periódicamente, cuando el venero autoficticio daba evidentes señales de agotarse, o porque sabía que los lectores esperaban y él les debía un relato auténtico de su vida, el escritor anunciaba un libro en el que contaría lo que hasta entonces nunca había contado. A veces, en un comentario como que no quiere la cosa, una alusión (Diario de un escritor burgués). Lo repitió en su último y fracasado libro Amado siglo $X X$, en el que alude a la "página pendiente” y a la palabra nunca dicha (“mi palabra sigo sin decirla”). Esa palabra que debía pronunciar, pues no podía esperar más... Espera inútil. Umbral se llevó su secreto. Para él fue una promesa imposible de cumplir. Nunca pudo afrontar ese reto, y esa imposibilidad da idea de la magnitud del problema que para él representó. Murió y nos quedamos sin la página prometida.

III

En la década de los años setenta la sociedad española estuvo polarizada por la política, fueron los años de la larga y lenta agonía del franquismo, que, como ya dije, duró más allá de la muerte del dictador, es decir, de la interminable transición a una democracia soñada que no acababa de llegar y el consiguiente desencanto. En lo literario, esos años estuvieron marcados en la literatura por el predominio de lo autobiográfico y por el boom editorial de los libros memorialísticos. La literatura autobiográfica de aquel momento fue un exponente más de la contradicción que representaba la necesidad de recuperar críticamente el pasado y la imposibilidad del heroísmo individual para hacerle frente de manera coherente. Una imposibilidad tanto más evidente cuanto más coercitivas resultaban las reglas del mercado y la desmemoria de lustros. Eran libros que querían rellenar con urgencia las lagunas de la memoria colectiva e individual, pero, salvo excepciones, resultaron pobres en sus resultados: demasiado adocenados en la forma y remisos a afrontar los desafíos éticos y personales a que obliga el pacto de 
veracidad. En ese contexto en que el público demandaba autobiografías y memorias verdaderas, la propuesta de los autobiógrafos se caracterizó por una respuesta timorata y de escaso valor literario, toda vez que no consiguieron superar el prejuicio de considerar la autobiografía una literatura de segunda división. No era una situación totalmente nueva sino que era el último estadio de una larga tradición. En ese contexto, la autoficción representó para algunos escritores una opción cómoda, pues les permitía regatear el compromiso autobiográfico y a la vez reivindicar sus relatos como literarios. Cuando la autoficción se reclama solo de la ficción, adopta casi siempre una mirada complaciente y domesticada de la realidad. Por el contrario, cuando reivindica también lo real, interroga a partes iguales la realidad de lo ficticio y la ficción de lo real. Dice el psicólogo infantil Donald Winnicott que en el juego infantil del escondite, al margen de sus importantes valores formativos y simbólicos, el niño descubre el inmenso placer de la ocultación, pero al mismo tiempo comprende la catástrofe que supone no ser encontrado. Ahí reside el atractivo de la autoficción, pero también su riesgo. Al diluir lo vivido en la ficción, Umbral se escondía a la vista de los demás y esquivaba su juicio, pero se condenó a no ser encontrado. La autoficción podría haber sido la atalaya privilegiada desde donde atisbar qué efectos, alteraciones o subversiones se producían en el encuentro aleatorio de lo biográfico y lo inventado en su vida, pero la tendencia a la fabulación lo apartó de ese objetivo. Al optar por contemplar todo como ficción, hizo muy poco para desmontar las supercherías. Desaprovechó la posibilidad que le brindaba la relación tensa entre lo vivido y lo escrito, otorgando la primacía a lo ficticio. Y en esta elección su obra se adelgazaba inevitablemente.

\section{Bibliografía citada}

Alberca, Manuel, El pacto ambiguo. De la novela autobiográfica a la autoficción, Madrid, Biblioteca Nueva, 2007.

Caballé, Anna, “Los comienzos de un escritor”, Boletín de la Unidad de Estudios Biográficos, 4, 1999.

Caballé, Anna, Francisco Umbral. El frío de una vida, Madrid, Espasa, 2004.

Colonna, Vicent, Autofiction \& autres mythomanies littéraires, Auch, Tristam, 2004. 
Darrieusecq, Marie, “L’autofiction, un genre pas sérieux”, Poétique, 107 (septiembre, 1996).

Doubrovsky, Serge, Fils, París, Galilée, 1977.

Fontana, Josep, La época del liberalismo. Historia de España (vol. 6), Crítica/Marcial Pons, Barcelona / Madrid, 2007.

Gasparini, Philippe, Autofiction. Une aventure du langage, París, Seuil, 2008.

Hernando de Larramendi, Miguel, y otros (eds.), Autobiografía y literatura árabe, Toledo, Escuela de Traductores / Universidad de Castilla-La Mancha, 2001.

Lejeune, Philippe, Le pacte autobiographique, París, Seuil, 1975.

« Antifiction », Poétique, 149 (febrero 2007).

Todorov, Tzvetan, Introduction à la littérature fantastique, París, Seuil, 1970.

Obras citadas de Francisco Umbral

(“novelas de la madre y la provincia”)

Memorias de un niño de derechas (1972); Retrato de un joven malvado (Memorias prematuras) (1972); Los males sagrados (1973); Mortal y rosa (1975); Las ninfas (1976); Diario de un escritor burgués (1979); Los helechos arborescentes (1980); Las ánimas del purgatorio (1982); El hijo de Greta Garbo (1982); Las giganteas (1982); Pío XII, la escolta mora y un general sin ojo (1985); El fulgor de África (1989); La leyenda del César Visionario (1991); Las Señoritas de Aviñón (1995); Los cuadernos de Luis Vives (1996).

Recibido: 15 junio 2012

Aceptado: 26 junio 2012

Publicado: 31 julio 2012

Actualizado: 3 septiembre 2012 